\title{
Sedimentary environmental change induced from late Quaternary sea-level change in the Bonaparte Gulf, northwestern Australia
}

\author{
Takeshige Ishiwa ${ }^{1,2^{*}} \mathbb{D}$, Yusuke Yokoyama ${ }^{1,2^{*}}$, Yosuke Miyairi ${ }^{1}$, Minoru Ikehara ${ }^{3}$ and Stephen Obrochta ${ }^{4}$
}

\begin{abstract}
Low-latitude continental shelves, mixed siliciclastic-carbonate sedimentary systems, provide an understanding of sedimentary environments driven by paleoclimatological processes. The Bonaparte Gulf, northwestern Australian continental shelf, is among the widest in the world, ranging to $500 \mathrm{~km}$, with shallow carbonate terraces and platforms that were exposed during periods of lower sea level. The dominant sediments type switches between carbonate and siliciclastic over a sea-level cycle. However, the mechanism of sedimentary environmental change in the Bonaparte Gulf is not clearly understood. Here, we present a record of sedimentary environmental change from ca. 24 to $35 \mathrm{ka}$ that is related to sea-level variability and exposure of carbonate terraces and platforms. Multi-proxy data from a marine sediment core show a sea-level change induced switch in sedimentary environment from siliciclastic to carbonate-dominated sedimentation during the last glaciation. Radiocarbon ages constrain the timing of this switch to ca. $26 \mathrm{ka}$, associated with a local sea-level fall of $-90 \mathrm{~m}$.
\end{abstract}

Keywords: Sedimentary environment, Radiocarbon dating, Bonaparte Gulf, Northwestern Australia, Last Glacial Maximum, Sea-level change

\section{Background}

Continental shelves are the main transport pathway of sediments from land to sea, playing an important role in the earth's surface system. The sedimentary environment of low-latitude mixed siliciclastic-carbonate continental shelves is strongly influenced by sea-level change and fluvial processes (Dunbar and Dickens 2003; Schlager et al. 1994; Webster et al. 2012). Detailed research on sedimentary environments of continental shelves improves our understanding of monsoonal intensity and sea-level variability (Bourget et al. 2012; Yokoyama et al. 2000).

The Bonaparte Gulf, northwestern Australia, is a broad continental shelf with a water depth shallower than 200 m (Bourget et al. 2013, 2014). The area of the shelf has varied with relative sea-level change during the late Quaternary (Yokoyama et al. 2001a). There are

\footnotetext{
*Correspondence: t_ishiwa@aori.u-tokyo.ac.jp;

yokoyama@aori.u-tokyo.ac.jp

${ }^{1}$ Atmosphere and Ocean Research Institute, The University of Tokyo,

5-1-5 Kashiwanoha, Kashiwa, Chiba 277-8564, Japan

Full list of author information is available at the end of the article
}

several carbonate terraces and platforms such as Londonderry, Sahul, and van Diemen Rise in the Bonaparte Gulf, which were exposed during sea-level lowstands (Fig. 1; Bourget et al. 2013, 2014; van Andel et al. 1967). Carbonate terraces and platforms contain incisions at depths exceeding $100 \mathrm{~m}$, connecting the Timor Sea and Bonaparte Basin (Courgeon et al. 2016). Siliciclastic sediments, transported by monsoon-influenced fluvial activity, dominate the near-shore region (Fig. 1; De Deckker et al. 2014; Nicholas et al. 2014). Shallow sediment cores show that past relative sea level fell to $\sim-120 \mathrm{~m}$ in the Bonaparte Gulf during the Last Glacial Maximum (LGM; 20 ka) (De Deckker and Yokoyama 2009; Ishiwa et al. 2016; Yokoyama et al. 2000, 2001b; Nakada et al. 2016).

Today, northwestern Australia experiences a semi-arid climate. Southeast winds prevail in the Austral summer and northwesterly winds in the Austral winter. There is a strong rainfall seasonality during the Austral summer (De Deckker et al. 2014; Gallagher et al. 2014a). This is the Australian monsoon, the intensity of which has 


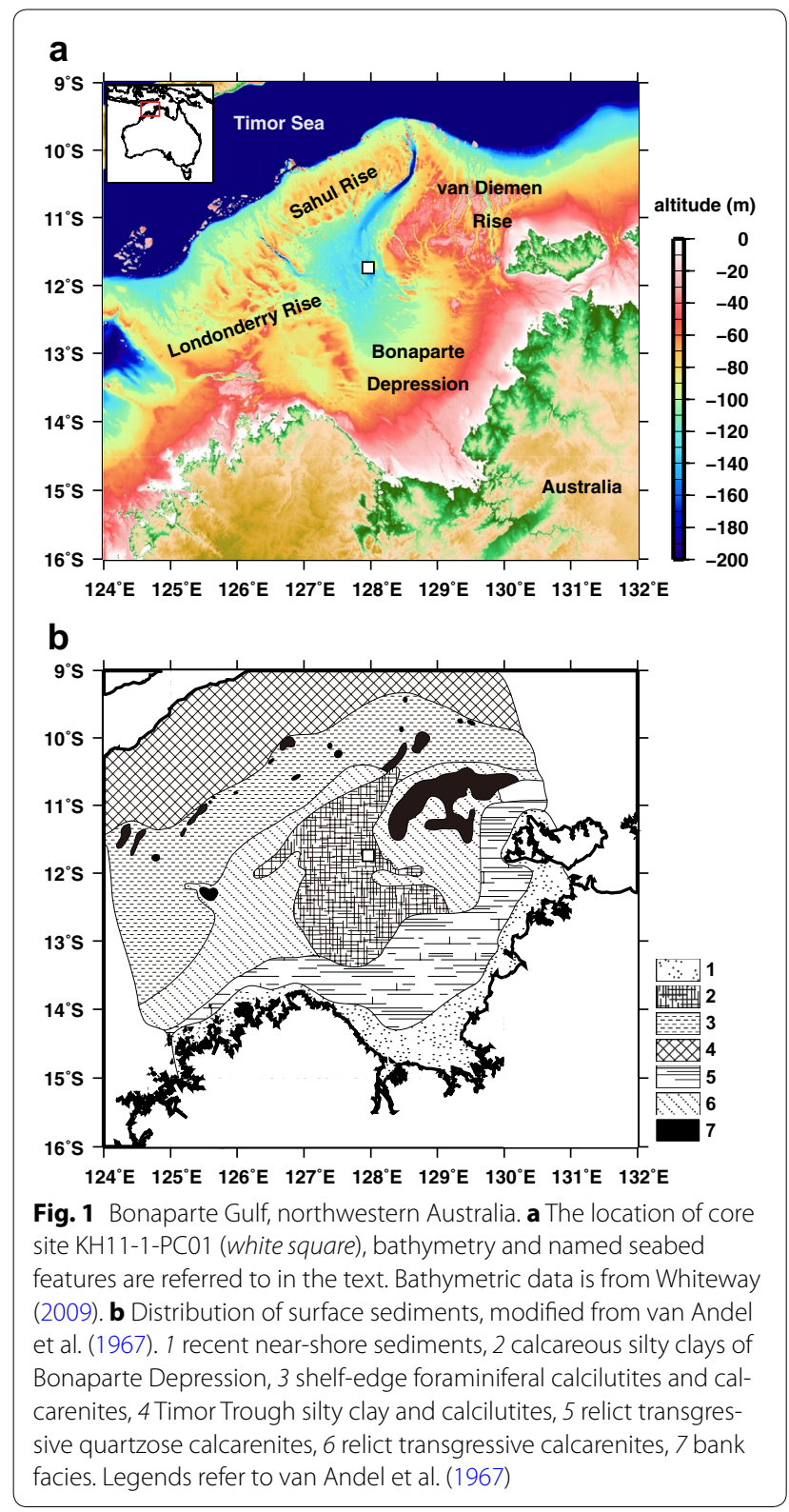

varied with the movement of the Intertropical Convergence Zone (ITCZ) over the past 30,000 years (cf., Ding et al. 2013; Kuhnt et al. 2015; Mohtadi et al. 2011).

This mixed siliciclastic-carbonate and shallow continental shelf is influenced by monsoonal intensity and sea-level change (Gallagher et al. 2014b). Petroleum exploration and paleoclimatic reconstructions have driven interest in the long-term understanding of the sedimentary environment in this region (Anderson et al. 2011; Nicholas et al. 2014). Moreover, mixed siliciclastic-carbonate sedimentary environments in low-latitude and semi-enclosed marginal marine environments provide information on the mechanism of paleoclimatic and hydrologic change (cf., Bahr et al. 2005; Isaack et al. 2016; Soulet et al. 2011). However, our understanding of late Quaternary evolution of the Bonaparte sedimentary environment is much less well constrained.

Here, we document the evidence of environmental changes due to the exposure of these carbonate terraces and platforms before the LGM. The Bonaparte Gulf is a "far-field" (cf., Yokoyama and Esat 2011), tectonically stable site extremely suitable for reconstruction of sea level due to past continental ice-volume change (De Deckker and Yokoyama 2009; Ishiwa et al. 2016; Yokoyama et al. 2000, 2001b). We also describe the sedimentary consequences of past environmental change from a marine piston core (KH11-1-PC01) using $\mathrm{Ca} / \mathrm{Ti}$ ratios, total organic carbon (TOC) and total nitrogen (TN), constrained by radiocarbon dating.

\section{Methods \\ Materials}

Core KH11-1-PC01 was recovered from a water depth of $140 \mathrm{~m}$ during the KH11-1 cruise of R/V HakuhoMaru during January and February 2011 (Fig. 1). The top $600 \mathrm{~cm}$ interval of core KH11-1-PC01 (core recovery length: $951 \mathrm{~cm}$ ) was analyzed as it is within the range of radiocarbon dating. Well-preserved macrofossils (primarily bivalves) were collected for radiocarbon dating.

\section{Physical properties and geochemical analysis}

Color reflectance was measured at 2-cm intervals after splitting the cores on ship using a Minolta CM-2002 photospectrometer. At the same time, magnetic susceptibility was measured at $2-\mathrm{cm}$ intervals using a Bartington Instruments MS2C system.

TOC and TN were measured using an EA-IRMS (Elemental Analysis-Isotope Ratio Mass Spectrometry: Flash EA 1112 and Delta plus Advantage) at the Center for Advanced Marine Core Research, Kochi University, Japan (cf., Ishiwa et al. 2016; Nakamura et al. 2016; Riethdorf et al. 2015). Bulk sediments were treated with $3 \mathrm{M}$ $\mathrm{HCl}$ to remove inorganic carbonate. Split-core scanning $\mathrm{X}$-ray fluorescence (XRF) analysis was later conducted at a 1-cm interval using the TATSCAN-F2 at the Center for Advanced Marine Core Research (Sakamoto et al. 2006). The XRF core scanner analysis was affected by split-core surface condition and water content, especially for the light elements (Kido et al. 2006; Nakamura et al. 2016). Hence, we discuss the variation of relatively heavy elements, calcium $(\mathrm{Ca})$, and titanium (Ti). The flux of $\mathrm{Ca}$ and $\mathrm{Ti}$ is calculated as follows,

$$
\begin{aligned}
& \text { MAR }=\mathrm{DBD} \times \mathrm{LSR} \\
& \mathrm{Ca}(\mathrm{Ti}) \text { flux }=\text { MAR } \times \mathrm{Ca}(\mathrm{Ti})(\text { counts })
\end{aligned}
$$


where MAR is the mass accumulation rate $\left(\mathrm{g} / \mathrm{cm}^{2}\right.$ year), DBD is the dry bulk density $\left(\mathrm{g} / \mathrm{cm}^{2}\right)$, and LSR is the linear sedimentation rate $(\mathrm{cm} /$ year).

Radiocarbon dating was performed on marine macrofossils (Table 1) and bulk sediment organic matter. Macrofossils were etched by $10 \mathrm{M} \mathrm{HCl}$ to remove secondary and contaminating calcium carbonate (Yokoyama et al. 2016a). Bulk sediments were pretreated twice in $3 \mathrm{M} \mathrm{HCl}$ for $12 \mathrm{~h}$ to digest inorganic calcium carbonate (Ishiwa et al. 2016). We followed the methods of Yokoyama et al. (2007) in the graphitization and measured the graphite by the Single Stage Accelerator Mass Spectrometry (Yokoyama et al. 2016b) and the Micro Analysis Laboratory Tandem Accelerator at the University of Tokyo.

\section{Age-depth model}

Calendar ages were calculated using Oxcal (Ramsey and Lee 2013) with Marine 13 and Intcal 13 (Reimer et al. 2013) as calibration curves for macrofossils and organic matter ages. The local reservoir correction, $\Delta \mathrm{R}$, is undefined in the Bonaparte Gulf but expected to be minor (cf., O'Connor et al. 2010). Thus, we made no local correction, consistent with previous works (Ishiwa et al. 2016; Yokoyama et al. 2000, 2001b).

The age-depth model of KH11-1-PC01 was constrained using the BACON model (Blaauw and Christen 2011) based on macrofossil ages, since organic matter ages are affected by the transportation time of terrigenous components (cf., Ishiwa et al. 2016; Nakamura et al. 2016). This model uses the Bayesian analysis and Monte Carlo methods to constrain the smoothing age-depth model using the R statistical software package (cf., De Vleeschouwer et al. 2012; Shanahan et al. 2012).

Calculation for exposure percentage in the Bonaparte Gulf The area of carbonate terraces and platforms in the Bonaparte Gulf exposed during lower sea level was calculated using the bathymetric dataset from Whiteway (2009). The data were interpolated to a uniform resolution of 0.5 min latitudinally and longitudinally. We calculated the area of exposure along the sea-level curve and set the exposure percentage to $0 \%$ at relative sea level $=0 \mathrm{~m}$ and to $100 \%$ at relative sea level $=-120 \mathrm{~m}$. This percentage was calculated at a 5-m interval.

\section{Results}

\section{Lithology and physical properties}

The interval from 600 to $560 \mathrm{~cm}$ of core KH11-1-PC01 is silty clay with $\mathrm{mm}$-scale shell fragments. Fine sand is present from 560 to $520 \mathrm{~cm}$ and silty clay occurs from 520 to $510 \mathrm{~cm}$ with shell fragments, foraminifers and nannofossils (as noted in shipboard smear slides). Fine sand is present from 510 to $490 \mathrm{~cm}$ and silty clay with shell fragments, and nannofossils from 490 to $60 \mathrm{~cm}$. The upper $60 \mathrm{~cm}$ of core is silt and clay with shell fragments and bioturbation. Color reflectance $\left(b^{*}\right)$ values gradually increase from 1 to 9 in the uppermost $300 \mathrm{~cm}$ with a slight shift at $200 \mathrm{~cm}$, indicating an increasing yellow component. A relatively large increase in $b^{*}$ occurs at $30 \mathrm{~cm}$ (Fig. 2). Magnetic susceptibility (MS) shows a slight decrease from 7 to 4 SI $10^{-6}$ at $200 \mathrm{~cm}$ with a maximum of $11 \mathrm{SI}^{-6} 0^{-6}$ at $10 \mathrm{~cm}$. In the upper $10 \mathrm{~cm}$, the MS decreases to 0 SI $10^{-6}$ (Fig. 2).

Table 1 Age results of macrofossils in core KH11-1-PC01

\begin{tabular}{|c|c|c|c|c|c|}
\hline Lab. No. & Material & Depth $(\mathrm{cm})$ & ${ }^{14} \mathrm{C}$ age (BP) & Calendar age (cal BP) $1 \sigma$ & Calendar age (cal BP) $2 \sigma$ \\
\hline YAUT-01960 & Bivalves & 1 & $2320 \pm 30$ & $1940 \pm 40$ & $1940 \pm 90$ \\
\hline YAUT-01960 & Bivalves & 3 & $10,510 \pm 40$ & $11,730 \pm 140$ & $11,670 \pm 260$ \\
\hline YAUT-01960 & Bivalves & 22 & $9750 \pm 40$ & $10,650 \pm 50$ & $10,660 \pm 110$ \\
\hline YAUT-01960 & Bivalves & 31 & $18,370 \pm 50$ & $21,770 \pm 100$ & $21,750 \pm 200$ \\
\hline B274 & Coral & 43 & $590 \pm 130$ & $200 \pm 140$ & - \\
\hline YAUT-01961 & Bivalves & 64 & $20,290 \pm 70$ & $23,930 \pm 120$ & $23,920 \pm 250$ \\
\hline YAUT-01961 & Bivalves & 74 & $20,290 \pm 70$ & $23,940 \pm 120$ & $23,930 \pm 250$ \\
\hline YAUT-01961 & Bivalves & 133 & $20,940 \pm 70$ & $24,710 \pm 180$ & $24,730 \pm 320$ \\
\hline B274 & Bivalves & 166 & $20,950 \pm 140$ & $24,740 \pm 240$ & $24,760 \pm 430$ \\
\hline YAUT-01964 & Bivalves & 173 & $20,910 \pm 70$ & $24,660 \pm 170$ & $24,690 \pm 310$ \\
\hline B274 & Bivalves & 217 & $23,320 \pm 210$ & $27,270 \pm 200$ & $27,160 \pm 450$ \\
\hline YAUT-01961 & Bivalves & 218 & $23,280 \pm 70$ & $27,250 \pm 100$ & $27,240 \pm 200$ \\
\hline YAUT-01962 & Bivalves & 291 & $24,280 \pm 90$ & $27,890 \pm 100$ & $27,920 \pm 220$ \\
\hline B274 & Barnacle & 368 & $25,330 \pm 280$ & $28,990 \pm 300$ & $29,020 \pm 610$ \\
\hline B274 & Gastropod & 560 & $30,060 \pm 230$ & $33,820 \pm 190$ & $33,820 \pm 410$ \\
\hline B274 & Bivalves & 603 & $35,020 \pm 550$ & $39,160 \pm 580$ & $39,270 \pm 1280$ \\
\hline
\end{tabular}

Data are calculated by Marine13 (Reimer et al. 2013). "YAUT-" is a laboratory number of the Single Stage Accelerator Mass Spectrometry at the University of Tokyo. "B274" is a laboratory number of the Micro Analysis Laboratory Tandem Accelerator at the University of Tokyo 


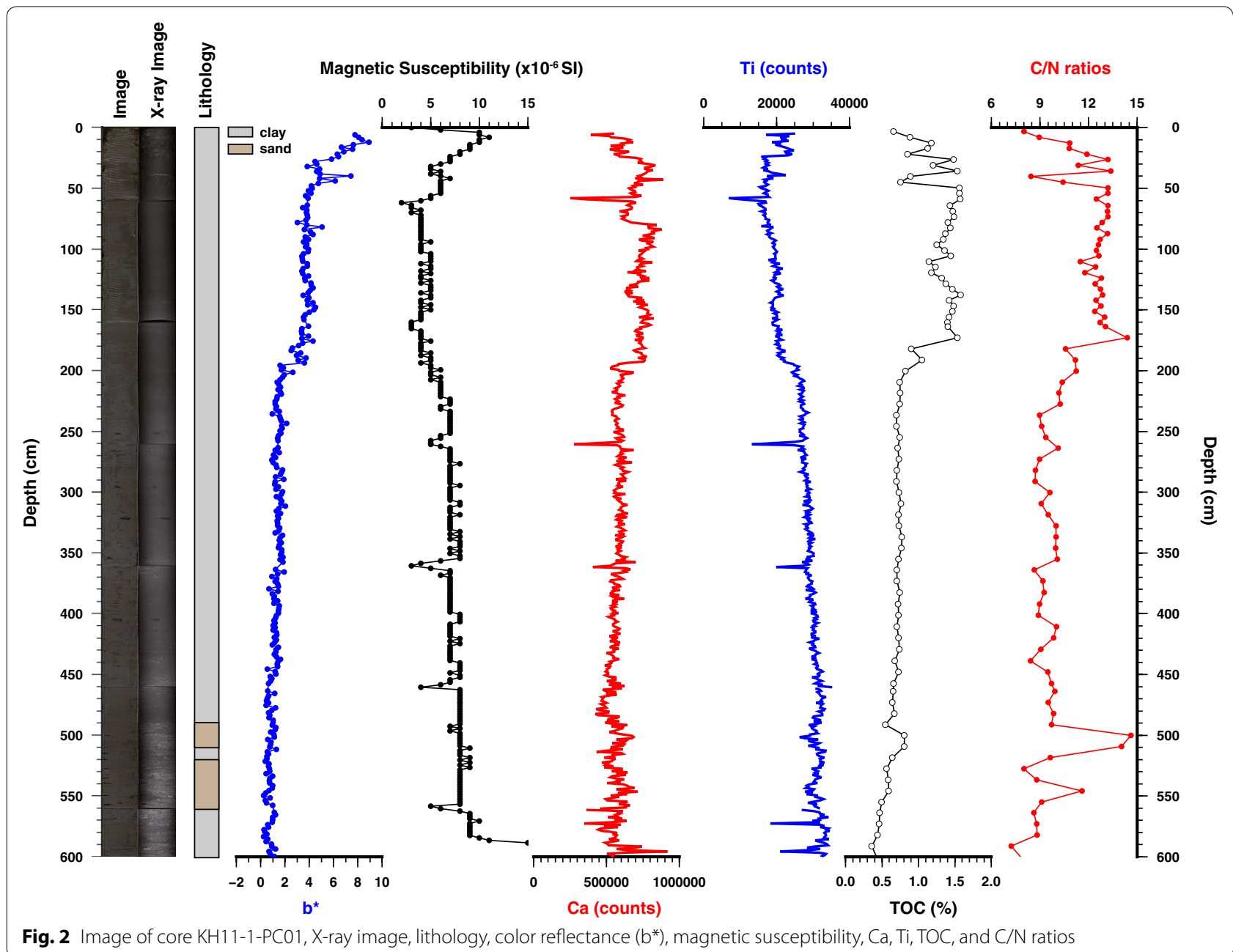

\section{XRF core scanning and geochemical analysis}

Ca counts are constant at 600,000 from 600 to $200 \mathrm{~cm}$, increasing to $\sim 800,000$ counts at $180 \mathrm{~cm}$ (Fig. 2). There is a sharp drop at $70 \mathrm{~cm}$. From $30 \mathrm{~cm}$ to the core top, Ca decreases to 400,000 counts. Ti counts gradually decrease from 600 to $200 \mathrm{~cm}$, sharply decreasing to 20,000 counts at $\sim 200 \mathrm{~cm}$ (Fig. 2). There is a peak of $\sim 25,000$ counts from $30 \mathrm{~cm}$ to the core top.

TOC is $\sim 0.7 \%$ from 600 to $200 \mathrm{~cm}$, sharply increasing to $1.5 \%$ at $\sim 180 \mathrm{~cm}$ with a peak of $\sim 0.8 \%$ at $\sim 510 \mathrm{~cm}$ (Fig. 2). TOC is variable in the upper $40 \mathrm{~cm}$ of core. $\mathrm{C} / \mathrm{N}$ ratios reach a maximum of $\sim 15$ at $510 \mathrm{~cm}$, then maintain a value of $\sim 9$ through the depth interval of $500-180 \mathrm{~cm}$, above which values are relatively constant at $\sim 13$ (Fig. 2). In the upper $60 \mathrm{~cm}$, ratios decrease upwards to the core top.

\section{Radiocarbon dating}

Tables 1 and 2 summarize the results of radiocarbon dating and Fig. 3 shows the age-depth relationship.
Macrofossils dates show the range from ca. 35 to $24 \mathrm{ka}$ and bulk organic matter from ca. 37 to 25 ka during the interval of $600-60 \mathrm{~cm}$. The upper $60 \mathrm{~cm}$ is either disturbed by coring or winnowed by tidal currents (http:// www.bom.gov.au/australia/tides/) and pockmark activity (Nicholas et al. 2014), and the ages in this interval are not interpreted here (Fig. 3). Below $60 \mathrm{~cm}$, the age-depth model is well constrained with an offset between macrofossils and organic matter ages (cf., Ishiwa et al. 2016). The average value of this offset is $\sim 800{ }^{14} \mathrm{C}$ year within the period from ca. 35 to $25 \mathrm{ka}$ and $\sim 1200{ }^{14} \mathrm{C}$ year with the period from ca. 25 to $24 \mathrm{ka}$. The average sedimentation rate is $0.47 \mathrm{~m} / \mathrm{kyr}$ for the period from ca. 35 to $25 \mathrm{ka}$ and $0.75 \mathrm{~m} / \mathrm{kyr}$ for the period from ca. 25 to $24 \mathrm{ka}$.

\section{Exposure of carbonate terraces and platforms in Bonaparte Gulf}

Figure 4a shows the calculated percentage of exposure and the rate of sea-level change from 0 to $-120 \mathrm{~m}$ in $5 \mathrm{~m}$ increments. During sea-level lowstands, the proportion 
Table 2 Age results of organic matter in core KH11-1-PC01

\begin{tabular}{lcccc}
\hline Lab. No. & Depth $(\mathbf{c m})$ & ${ }^{\mathbf{1 4}} \mathbf{C}$ age $(\mathbf{B P})$ & Calendar age (cal BP) $\mathbf{1 \sigma}$ & Calendar age (cal BP) $\mathbf{2 \sigma}$ \\
\hline YAUT-003718 & 3 & $1790 \pm 30$ & $1700 \pm 80$ & $1720 \pm 100$ \\
YAUT-003906 & 22 & $7650 \pm 30$ & $8430 \pm 20$ & $8450 \pm 60$ \\
YAUT-003719 & 45 & $7040 \pm 70$ & $7870 \pm 70$ & $7840 \pm 140$ \\
YAUT-012705 & 54 & $21,040 \pm 80$ & $25,400 \pm 120$ & $25,390 \pm 230$ \\
YAUT-003907 & 74 & $21,450 \pm 60$ & $25,780 \pm 80$ & $25,770 \pm 150$ \\
YAUT-004007 & 101 & $21,180 \pm 70$ & $25,540 \pm 110$ & $25,510 \pm 220$ \\
YAUT-003720 & 133 & $22,200 \pm 110$ & $26,390 \pm 170$ & $26,440 \pm 350$ \\
YAUT-003721 & 173 & $21,780 \pm 100$ & $26,000 \pm 90$ & $26,010 \pm 200$ \\
YAUT-003722 & 218 & $25,060 \pm 110$ & $29,090 \pm 170$ & $29,110 \pm 320$ \\
YAUT-014534 & 255 & $24,370 \pm 90$ & $28,440 \pm 150$ & $28,420 \pm 280$ \\
YAUT-004008 & 291 & $29,120 \pm 160$ & $29,140 \pm 300$ \\
YAUT-003723 & 369 & $26,360 \pm 130$ & $30,700 \pm 150$ & $30,660 \pm 300$ \\
YAUT-003724 & 555 & $30,600 \pm 150$ & $34,560 \pm 170$ & $34,530 \pm 330$ \\
YAUT-003725 & 600 & $32,810 \pm 200$ & $36,720 \pm 330$ & $36,930 \pm 680$ \\
\hline
\end{tabular}

Data are calculated by Intcal 13 (Reimer et al. 2013). "YAUT-" is a laboratory number of the Single Stage Accelerator Mass Spectrometry at the University of Tokyo

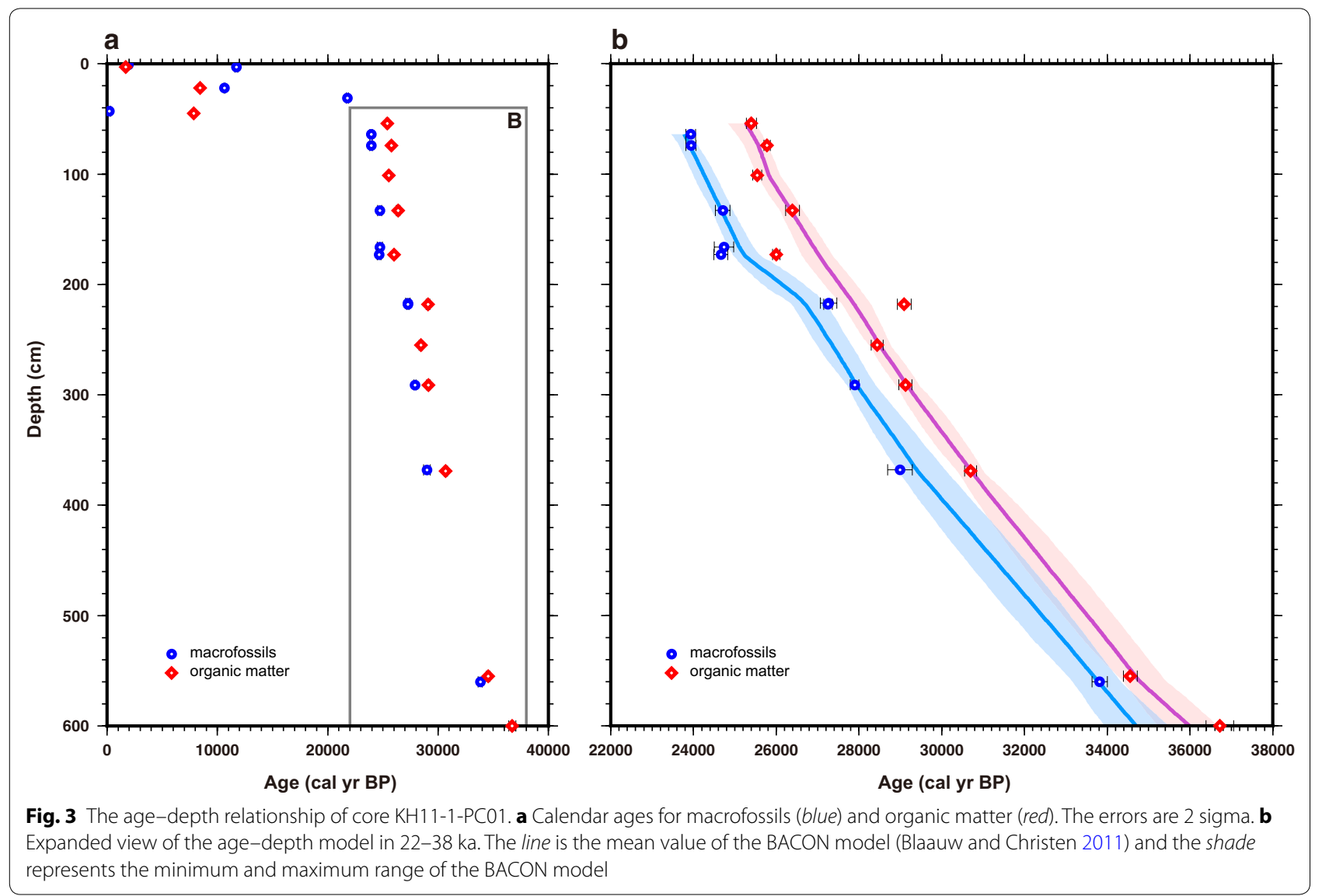

of carbonate terraces and platforms exposed in Bonaparte Gulf ranged from $25 \%$ when sea level was at $-60 \mathrm{~m}$ to in excess of $90 \%$ when sea level fell below $-100 \mathrm{~m}$.
The rate of change from -70 to $-90 \mathrm{~m}$ is greater than $1.5 \% / \mathrm{m}$. The maximum rate of change is at $-80 \mathrm{~m}$ (Fig. 4b). 


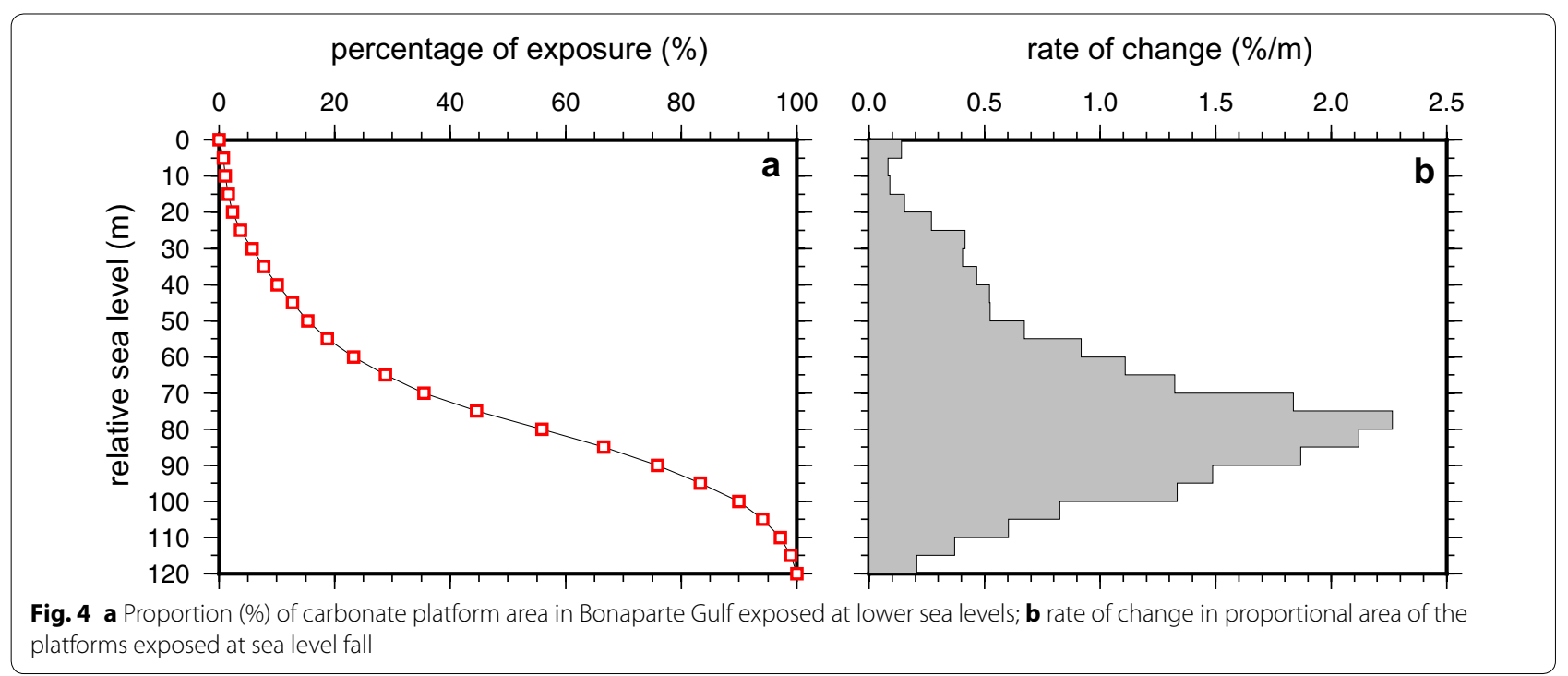

\section{Interpretation and discussion \\ Sedimentary environmental change during late \\ Quaternary}

Biogenic or precipitated carbonate shows high $\mathrm{Ca}$ intensities with an inverse relationship to $\mathrm{K}-, \mathrm{Fe}-, \mathrm{Mn}-$, and $\mathrm{Ti}$ - intensities that are correlated with siliciclastic components (cf., Bahr et al. 2005; Kuhnt et al. 2015). $\mathrm{Ca} / \mathrm{Ti}, \mathrm{Ca} / \mathrm{K}, \mathrm{Ca} / \mathrm{Mn}$ and $\mathrm{Ca} / \mathrm{Fe}$ all exhibit a similar pattern of variability (see Additional file 1: Figure S1). Thus, we focus on $\mathrm{Ca} / \mathrm{Ti}$, which is less sensitive to redox changes. We suggest that calcium variation represents changes in biogenetic carbonate flux from the carbonate terraces and platform of the Bonaparte Gulf (Fig. 5; and see Additional file 1: Figure S2). The Ca flux after $25 \mathrm{ka}$ is much higher than before $27 \mathrm{ka}$, indicating a carbonate flux increase caused by exposure of the carbonate platforms during lower sea level at ca. $26 \mathrm{ka}(190 \mathrm{~cm})$ (Fig. 5). In addition, we use the titanium variation to represent terrigenous sediment flux, derived from clay minerals (cf., Gingele et al. 2001; Gingele and De Deckker 2003). Magnetic susceptibility values decrease from 27 to $25 \mathrm{ka}$ (Fig. 6). This pattern likely reflects the dilution by sediments dominated by biogenetic carbonate with low magnetic susceptibility.

The variation in terrigenous input is interpreted to be related to changes in TOC flux and $\mathrm{C} / \mathrm{N}$ ratios (cf., Ishiwa et al. 2016; Yu et al. 2010; Mackie et al. 2005). The terrigenous sediment supply increased after ca. $26 \mathrm{ka}$, as indicated by the increased TOC, $\mathrm{C} / \mathrm{N}$ ratios, and sedimentation rate (Figs. 5, 6). Increased terrigenous material during this time would make mixed marine-terrigenous organic matter older, increasing the offset from macrofossil ages (Fig. 3). Additionally, mass accumulation rate calculated by the BACON model supports the exposure of carbonate terraces and platforms during this period (Fig. 5).

\section{Mechanism for sedimentary environmental change}

The carbonate terraces and platforms of the outer Bonaparte Gulf are dissected by a network of deeply incised paleochannels that would have provided sediment transport pathways during lower sea level (Courgeon et al. 2016; Fig. 7; see also Additional file 1: Figure S3). Yokoyama et al. (2000, 2001b) estimated the age of deposition in these paleochannels to be ca. $17.5 \mathrm{ka}$, suggesting that carbonate sediments were produced and transported to the depression during lower sea level by fluvial activity or ocean currents.

Sedimentation patterns would have fluctuated with the relative strength of monsoon (Gallagher et al. 2014b; Kuhnt et al. 2015). The Australian Monsoonal precipitation pattern is sensitive to latitudinal ITCZ migration (Lewis et al. 2011), while speleothem records from this region indicate low monsoon variability at this time (Lewis et al. 2011; Partin et al. 2007), consistent with marine and terrestrial records (Fitzsimmons et al. 2013; Reeves et al. 2013) that show a northward ITCZ position. We suggest that the changes in monsoonal variability are not strong enough to control the sedimentary facies in the Bonaparte Gulf. A relative change in carbonate sediment flux increased at ca. $26 \mathrm{ka}$ as shown by physical properties and geochemical analysis (Fig. 5). Rivers passing through the continent would have supplied siliciclastic sediments to the depression (Gingele et al. 2001; 


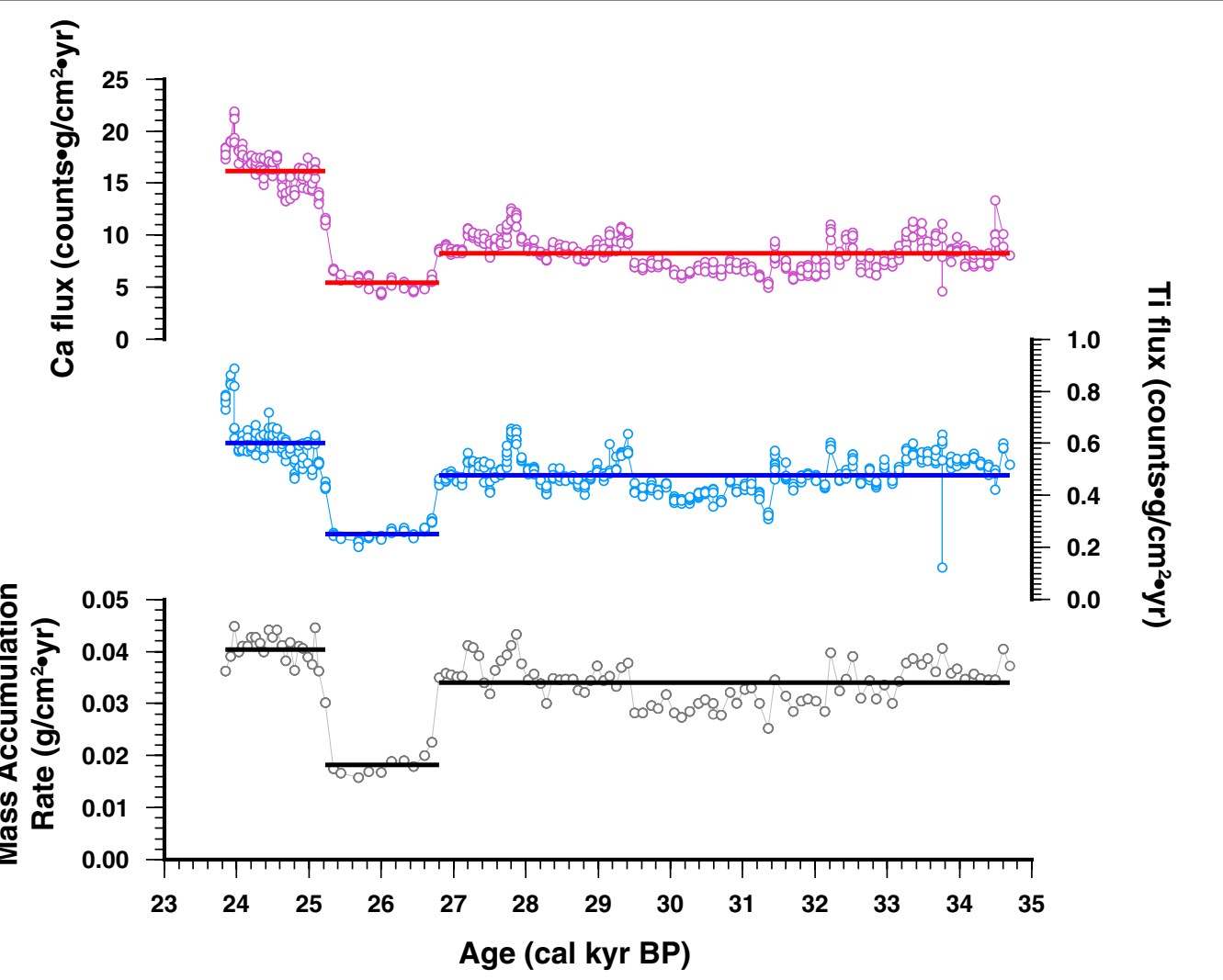

Fig. $5 \mathrm{Ca}$ flux, Ti flux, and mass accumulation rate. Solid lines correspond to the average values during three periods, before $\sim 27 \mathrm{ka}$, during 25-27 ka, and after $\sim 25 \mathrm{ka}$

Gingele and De Deckker 2003). During this period, the supply of siliciclastic sediments did not change much due to the weak variability of monsoonal intensity. By contrast, the carbonate supply increased due to the exposure of carbonate terraces and platforms.

Sea level below $-90 \mathrm{~m}$ resulted in sufficient exposure of carbonate terraces and platform to increase the flux of carbonate sediments (Fig. 7). During sea-level highstands, much of the shelf was submerged. During sealevel lowstands, the carbonate terraces and platforms were exposed and the Bonaparte Depression was semienclosed from the Timor Sea. The relative area of exposure was an important control on the sedimentary facies of the gulf.

While the hydro-isostatic effects in the Bonaparte Gulf do not significantly affect to the current interpretation (Yokoyama et al. 2000, 2001b), this factor cannot be entirely discounted due to paleotopography and paleo-water depth effects. Yokoyama et al. (2000, 2001b) estimated the amplitude of this effect (offset between the global sea level and relative sea level) is less than $20 \mathrm{~m}$. Therefore, the bathymetry in Fig. 7 has an error of $10 \%$ due to hydro-isostasy effects.

These observations indicate that the sedimentary environment in the Bonaparte Gulf is primarily driven by sealevel variability due to the distinctive topography with its central depression surrounded by higher-level carbonate terraces and platforms. Exposure of carbonate terraces and platforms with a sea-level fall enhances sedimentary environmental change, characterized by carbonate sediment production and transportation. Paleobathymetry would also likely have affected local ocean circulation patterns and tidal ranges.

Sea-level change prior to the LGM has been estimated using the uplifted coral on the Huon Peninsula, indicating that sea level fell from -70 to $-110 \mathrm{~m}$ from 30 to 24 ka (Cutler et al. 2003; Yokoyama et al. 2001c). This is consistent with sea level from the Red Sea (Siddall 


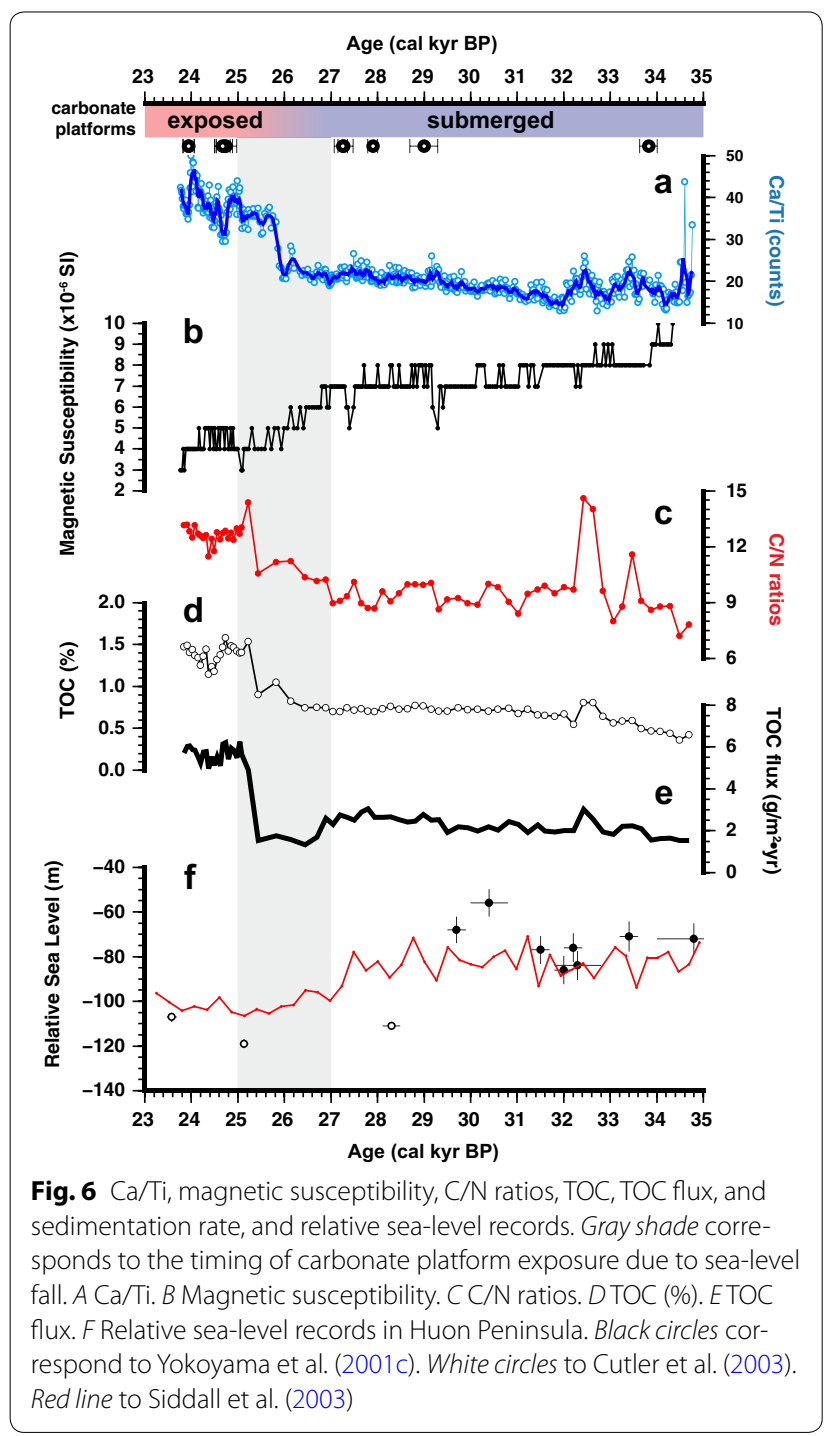

et al. 2003), which falls $\sim 20 \mathrm{~m}$ from 28 to $26 \mathrm{ka}$ ( -80 to $-100 \mathrm{~m})$.

\section{Comparison to other regions}

Mixed carbonate-siliciclastic sedimentary systems are observed in low-latitude tropical regions. Isaack et al. (2016) present a sea-level driven model of sediment dynamics based on a multi-proxy record in the barrierreef lagoon of Bora Bora in the South Pacific. They suggest that carbonate sediment produced in marginal reef areas is transported to the lagoons. This mechanism indicates that carbonate terraces and platforms in the Bonaparte Gulf can be the source of carbonate sediments, generating the variation of geochemical signal in the core.

The Black Sea became a semi-enclosed marginal sea, similar to the Bonaparte Gulf, during lowering sea levels (Bahr et al. 2005), and reconnected to the Mediterranean Sea at $\sim 9000$ years ago in association with rising sea level (Soulet et al. 2011). Geochemical data suggest that the hydrologic system has changed from lacustrine to marine, controlled by a water depth of sills connected to Mediterranean Sea. By contrast, during sea-level lowstands, the Bonaparte Gulf connected to the Timor Sea mainly by paleochannels at a water depth of $200 \mathrm{~m}$ (Fig. 1; Yokoyama et al. 2000, 2001a). The sedimentary environment in the Bonaparte Gulf is influenced by the exposure of carbonate terraces and platforms, which played a role in pathways of carbonate sediments.

\section{Conclusions}

Geochemical and chronological records from a piston core in the Bonaparte Gulf, northwestern Australia, show a sedimentary environmental change at ca. $26 \mathrm{ka}$. Carbonate terraces and platforms and their deeply incised paleochannels play an important role in this paleoenvironmental change.

$\mathrm{Ca} / \mathrm{Ti}$ ratios as an indicator of changes in mixed siliciclastic-carbonate sediments increased at ca. $26 \mathrm{ka}$, indicating the enhanced supply of carbonate sediments. TOC and $\mathrm{C} / \mathrm{N}$ ratios as an indicator of terrigenous input also increased. The changes in these geochemical signals can be explained by the exposure of carbonate terraces and platforms.

Precipitation patterns shift can drive the change in sediment supply. However, during the period we investigate, the variability of Australian monsoon was not strong enough to change the sedimentary environment. By contrast, global sea-level fall to $-90 \mathrm{~m}$ occurred at ca. $26 \mathrm{ka}$, driving the exposure of carbonate terraces and platforms and the switch from siliciclastic to carbonatedominated sedimentation. Our research provides an understanding of a sea-level driven sedimentary environmental change in low-latitude mixed siliciclastic-carbonate environment. 


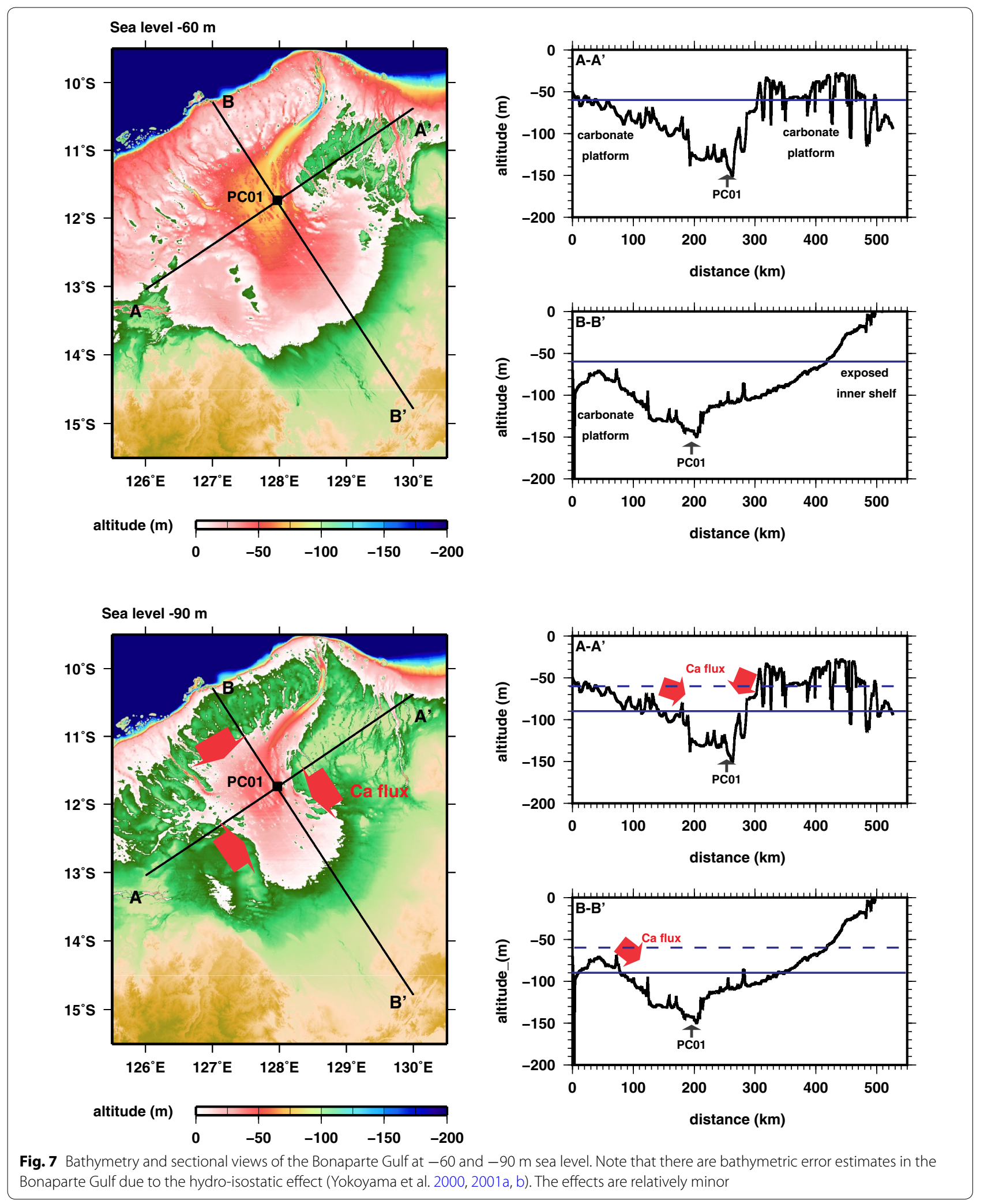




\section{Additional file}

Additional file 1. Additional figures.

\section{Abbreviations}

ITCZ: Intertropical Convergence Zone; LGM: last glacial maximum; TOC: total organic carbon; TN: total nitrogen; MAR: mass accumulation rate; DBD: dry bulk density; LSR: liner sedimentation rate; XRF: X-ray fluorescence; MS: magnetic susceptibility.

\section{Authors' contributions}

TI carried out this work and YY managed the cruise KH11-1 and also supervised this work. YM supported measurement of this work. MI managed measurement in CMCR and gave useful comments. SO interpreted results and helped to write the final manuscript. YY, YM, MI and SO joined the cruise of $\mathrm{KH} 11-1$. All authors read and approved the final manuscript.

\section{Author details}

${ }^{1}$ Atmosphere and Ocean Research Institute, The University of Tokyo, 5-1-5 Kashiwanoha, Kashiwa, Chiba 277-8564, Japan. ${ }^{2}$ Department of Earth and Planetary Science, Graduate School of Science, The University of Tokyo, 7-3-1 Hongo, Bunkyo, Tokyo 113-0033, Japan. ${ }^{3}$ Center for Advanced Marine Core Research, Kochi University, B200 Monobe, Nankoku, Kochi 783-8502, Japan. ${ }^{4}$ Faculty of International Resource Science, Akita University, 1-1 Tegata-Gakuenmachi, Akita, Akita 010-8502, Japan.

\section{Acknowledgements}

We greatly appreciate the members of the cruise of $\mathrm{KH} 11-1$ for collecting and subsampling the sediment cores. The reviewers, Dr. S. Nichol and Dr. S. Gallagher, gave us the useful and valuable comments to revise this paper. This study was supported by the Center for Advanced Marine Core Research (CMCR), Kochi University, cooperative research program (11A031, 11B039) and grants from the Japan Society for the Promotion of Science (JSPS) KAKENHI (JP26247085, JP15KK0151) and JSPS Fellows DC2 (16J04542).

\section{Competing interests}

The authors declare that they have no competing interests.

Received: 12 August 2016 Accepted: 29 November 2016

Published online: 07 December 2016

\section{References}

Anderson TJ, Nichol S, Radke L, Heap AD, Battershill C, Hughes M, Siwabessy PJ, Barrie V, Alvarez de Glasby B, Tran M, Daniell J (2011) Seabed environments of the Eastern Joseph Bonaparte Gulf, Northern Australia: GA0325/ Sol5117-Post-survey Report. Geosci Aust Record

Bahr A, Lamy F, Arz H, Kuhlmann H, Wefer G (2005) Late glacial to Holocene climate and sedimentation history in the NW Black Sea. Mar Geol 214:309-322

Blaauw M, Christen JA (2011) Flexible paleoclimate age-depth models using an autoregressive gamma process. Bayesian Anal 6:457-474

Bourget J, Ainsworth RB, Backé G, Keep M (2012) Tectonic evolution of the northern Bonaparte Basin: impact on continental shelf architecture and sediment distribution during the Pleistocene. Aust J Earth Sci 59:877-897

Bourget J, Ainsworth RB, Nanson R (2013) Origin of mixed carbonate and siliciclastic sequences at the margin of a "giant" platform during the Quaternary (Bonaparte Basin, NW Australia). In: Verwer K, Playton TE, Harris PM (eds) Deposits, architecture, and controls of carbonate margin, slope, and basinal settings, special publication 105. SEPM (Society for Sedimentary Geology), Tulsa

Bourget J, Ainsworth RB, Thompson S (2014) Seismic stratigraphy and geomorphology of a tide or wave dominated shelf-edge delta (NW Australia): process-based classification from 3D seismic attributes and implications for the prediction of deep-water sands. Mar Pet Geol 57:359-384
Courgeon S, Bourget J, Jorry SJ (2016) A Pliocene-Quaternary analogue for ancient epeiric carbonate settings: the Malita intrashelf basin (Bonaparte Basin, northwest Australia). AAPG Bull 100:565-595

Cutler KB, Edwards R, Taylor FW, Cheng H, Adkins J, Gallup C, Cutler PM, Burr GS, Bloom AL (2003) Rapid sea-level fall and deep-ocean temperature change since the last interglacial period. Earth Planet Sci Lett 206:253-271

De Deckker P, Yokoyama Y (2009) Micropalaeontological evidence for Late Quaternary sea-level changes in Bonaparte Gulf, Australia. Global Planet Chang 66:85-92

De Deckker P, Barrows TT, Rogers J (2014) Land e sea correlations in the Australian region: post-glacial onset of the monsoon in northwestern Western Australia. Quat Sci Rev 105:181-194

De Vleeschouwer F, Pazdur A, Luthers C, Streel M, Mauquoy D, Wastiaux C, Le Roux G, Moschen R, Blaauw M, Pawlyta J, Piotrowska N (2012) A millennial record of environmental change in peat deposits from the Misten bog (East Belgium). Quat Int 268:44-57

Ding X, Bassinot F, Guichard F, Fang NQ (2013) Marine Micropaleontology Indonesian Through flow and monsoon activity records in the Timor Sea since the last glacial maximum. Mar Micropaleontol 101:115-126

Dunbar GB, Dickens GR (2003) Massive siliciclastic discharge to slopes of the Great Barrier Reef Platform during sea-level transgression: constraints from sediment cores between $15^{\circ} \mathrm{S}$ and $16^{\circ} \mathrm{S}$ latitude and possible explanations. Sed Geol 162:141-158

Fitzsimmons KE, Cohen TJ, Hesse PP, Jansen J, Nanson GC, May J, Barrows TT, Haberlah D, Hilger A, Kell T, Larsen J, Lomax J, Treble P (2013) Late Quaternary palaeoenvironmental change in the Australian drylands. Quat Sci Rev 74:78-96

Gallagher SJ, Fulthorpe CS, Bogus KA (2014a) Reefs, oceans, and climate: a 5 million year history of the Indonesian Throughflow, Australian monsoon, and subsidence on the northwest shelf of Australia. International Ocean Discovery Program Scientific Prospectus 356

Gallagher SJ, Wallace MW, Hoiles PW, Southwood JM (2014b) Seismic and stratigraphic evidence for reef expansion and onset of aridity on the Northwest Shelf of Australia during the Pleistocene. Mar Pet Geol 57:470-481

Gingele FX, De Deckker P (2003) Fingerprinting Australia's rivers using clays and the application for the marine record of rapid climate change. Advances in Regolith. ANU Research Publications, pp 140-143

Gingele FX, De Deckker P, Hillenbrand CD (2001) Clay mineral distribution in surface sediments between Indonesia and NW Australia-source and transport by ocean currents. Mar Geol 179:135-146

Isaack A, Gischler E, Hudson JH, Anselmetti FS, Lohner A, Vogel H, Garbode E, Camoin GF (2016) A new model evaluating Holocene sediment dynamics: insights from a mixed carbonate-siliciclastic lagoon (Bora Bora, Society Islands, French Polynesia, South Pacific). Sed Geol 343:99-118

Ishiwa T, Yokoyama Y, Miyairi Y, Obrochta S, Sasaki T, Kitamura A, Suzuki A, Ikehara M, Ikehara K, Kimoto K, Bourget J, Matsuzaki H (2016) Reappraisal of sea-level lowstand during the Last Glacial Maximum observed in the Bonaparte Gulf sediments, northwestern Australia. Quat Int 397:373-379

Kido Y, Koshikawa T, Tada R (2006) Rapid and quantitative major element analysis method for wet fine-grained sediments using an XRF microscanner. Mar Geol 229:209-225

Kuhnt W, Holbourn A, Xu J, Opdyke B, De Deckker P, Mudelsee M (2015) Southern Hemisphere control on Australian monsoon variability during the late deglaciation and Holocene. Nat Commun 6:5916

Lewis SC, Gagan MK, Ayliffe LK, Zhao J, Hantoro WS, Treble PC, Hellstrom JC, LeGrande AN, Kelley M, Schmidt GA, Suwargadi BW (2011) Highresolution stalagmite reconstructions of Australian-Indonesian monsoon rainfall variability during Heinrich stadial 3 and Greenland interstadial 4. Earth Planet Sci Lett 303:133-142

Mackie EAV, Leng MJ, Lloyd JM, Arrowsmith C (2005) Bulk organic $\delta^{13} \mathrm{C}$ and $\mathrm{C} / \mathrm{N}$ ratios as palaeosalinity indicators within a Scottish isolation basin. $J$ Quat Sci 20:303-312

Mohtadi M, Oppo DW, Steinke S, Stuut JW, De Pol-holz R, Hebbeln D, Lückge A (2011) Glacial to Holocene swings of the Australian-Indonesian monsoon. Nature Geosci 4:540-544

Nakada M, Okuno J, Yokoyama Y (2016) Total meltwater volume since the Last Glacial Maximum and viscosity structure of Earth's mantle inferred from relative sea level changes at Barbados and Bonaparte Gulf and GIAinduced J2. Geophys J Int 204:1237-1253 
Nakamura A, Yokoyama Y, Maemoku H, Yagi H, Okamura M, Matsuoka H, Miyake N, Osada T, Pani Adhikari D, Dangol V, Ikehara M, Miyairi Y, Matsu zaki H (2016) Weak monsoon event at 4.2 ka recorded in sediment from Lake Rara, Himalayas. Quat Int 397:349-359

Nicholas WA, Nichol SL, Howard FJF, Picard K, Dulfer H, Radke LC, Carroll AG, Siwabessy PJW (2014) Pockmark development in the Petrel Sub-basin, Timor Sea, Northern Australia: seabed habitat mapping in support of $\mathrm{CO}_{2}$ storage assessments. Cont Shelf Res 83:129-142

O'Connor S, Ulm S, Fallon SJ, Barham A, Loch I (2010) Pre-bomb marine reservoir variability in the Kimberley Region, Western Australia. Radiocarbon 52:1158-1165

Partin JW, Cobb KM, Adkins JF, Clark B, Fernandez DP (2007) Millennial-scale trends in west Pacific warm pool hydrology since the Last Glacial Maximum. Nature 449:452-455

Ramsey CB, Lee S (2013) Recent and planned developments of the program oxcal. Radiocarbon 55:720-730

Reeves JM, Bostock HC, Ayliffe LK, Barrows TT, De Deckker P, Devriendt LS, Dunbar GB, Drysdale RN, Fitzsimmons KE, Gagan MK, Griffiths ML, Haberle SG, Jansen JD, Krause C, Lewis S, McGregor HV, Mooney SD, Moss P, Nanson GC, Purcell A, van der Kaars S (2013) Palaeoenvironmental change in tropical Australasia over the last 30,000 years - a synthesis by the OZINTIMATE group. Quat Sci Rev 74:97-114

Reimer PJ, Bard E, Bayliss A, Beck JW, Blackwell PG, Ramsey CB, Buck CE, Cheng $H$, Edwards RL, Friedrich M, Grootes PM, Guilderson TP, Haflidason $H_{\text {, }}$ Hajdas I, Hatte C, Heaton TJ, Hoffmann DL, Hogg AG, Hughen KA, Kaiser KF, Kromer B, Manning SW, Niu M, Reimer RW, Richards DA, Scott EM, Southon JR, Staff RA, Turney CSM, van der Plicht J (2013) Intcal13 and marine 13 radiocarbon age calibration curves $0-50,000$ years cal bp. Radiocarbon 55:1869-1887

Riethdorf JR, Thibodeau B, Ikehara M, Nurnberg D, Max L, Tiedemann R, Yokoyama Y (2015) Surface nitrate utilization in the Bering sea since 180kA BP: insight from sedimentary nitrogen isotopes. Deep Sea Res Part II Top Stud Oceanogr:1-14

Sakamoto T, Kuroki K, Sugawara T, Aoike K, lijima K, Sugisaki S (2006) Nondestructive X-Ray fluorescence (XRF) core-imaging scanner, TATSCAN-F2. Sci Drill 2:37-39

Schlager W, Reijmer JJG, Droxler A (1994) Highstand shedding of carbonate platforms. J Sediment Res B64:270-281

Shanahan TM, Beck JW, Overpeck JT, MCKay NP, Pigati JS, Peck JA, Scholz CA, Heil CW, King J (2012) Late Quaternary sedimentological and climate changes at Lake Bosumtwi Ghana: new constraints from laminae analysis and radiocarbon age modeling. Palaeogeogr Palaeoclimatol Palaeoecol 361-362:49-60

Siddall M, Rohling E, Almogi-Labin A, Hemleben C, Meischner D, Schmelzer I, Smeed DA (2003) Sea-level fluctuations during the last glacial cycle. Nature 423:853-858
Soulet G, Ménot G, Lericolais G, Bard E (2011) A revised calendar age for the last reconnection of the Black Sea to the global ocean. Quat Sci Rev 30:1019-1026

van Andel T, Heath G, Moore T, McGeary DF (1967) Late Quaternary history, climate, and oceanography of the Timor Sea northwestern Australia. Am J Sci 265:737-758

Webster JM, Beaman RJ, Puga-Bernabeu A, Ludman D, Renema W, Wust RAJ, George NPJ, Reimer PJ, Jacobsen GE, Moss P (2012) Late Pleistocene history of turbidite sedimentation in a submarine canyon off the northern Great Barrier Reef, Australia. Palaeogeogr Palaeoclimatol Palaeoecol $331-332: 75-89$

Whiteway T (2009) Australian Bathymetry and Topography Grid, June 2009. Scale 1:5000000. Geoscience Australia, Canberra

Yokoyama Y, Esat TM (2011) Global climate and sea level: enduring variability and rapid fluctuations over the past 150,000 years. Oceanography 24:54-69

Yokoyama Y, Lambeck K, De Deckker P, Johnston P, Fifield LK (2000) Timing of the Last Glacial Maximum from observed sea-level minima. Nature 406:713-716

Yokoyama Y, Purcell A, Lambeck K, Johnston P (2001a) Shore-line reconstruction around Australia during the Last Glacial Maximum and Late Glacial Stage. Quat Int 83-85:9-18

Yokoyama Y, De Deckker P, Lambeck K, Johnston P, Fifield L (2001b) Sea-level at the Last Glacial Maximum: evidence from northwestern Australia to constrain ice volumes for oxygen isotope stage 2. Palaeogeogr Palaeoclimatol Palaeoecol 165:281-297

Yokoyama Y, Esat TM, Lambeck K (2001c) Coupled climate and sea-level changes deduced from Huon Peninsula coral terraces of the last ice age. Earth Planet Sci Lett 193:579-587

Yokoyama Y, Miyairi Y, Matsuzaki H, Tsunomori F (2007) Relation between acid dissolution time in the vacuum test tube and time required for graphitization for AMS target preparation. Nucl Instrum Meth Phys 259:330-334

Yokoyama Y, Maeda Y, Okuno J, Miyairi Y, Kosuge T (2016a) Holocene Antarctic melting and lithospheric uplift history of the southern Okinawa trough inferred from mid- to late-Holocene sea level in Iriomote Island, Ryukyu, Japan. Quat Int 397:342-348

Yokoyama Y, Anderson JB, Yamane M, Simkins LM, Miyairi Y, Yamazaki T, Koizumi M, Suga H, Kusahara K, Prothro L, Hasumi H, Southon JR, Ohkouch N (2016b) Widespread collapse of the Ross Ice Shelf during the late Holocene. Proc Natl Acad Sci 113:2354-2359

Yu F, Zong Y, Lloyd JM, Huang G, Leng MJ, Kendrick C, Lamb AL, Yim WWS (2010) Bulk organic d13C and C/N as indicators for sediment sources in the Pearl River delta and estuary, southern China. Estuar Coast Shelf Sci $87: 618-630$

\section{Submit your manuscript to a SpringerOpen ${ }^{\circ}$ journal and benefit from:}

- Convenient online submission

- Rigorous peer review

- Immediate publication on acceptance

- Open access: articles freely available online

- High visibility within the field

- Retaining the copyright to your article

Submit your next manuscript at springeropen.com 